\title{
Soil Respiration from Different Halophytic Plants in Coastal Saline-Alkali Soils
}

\author{
Xiaoguang Li ${ }^{1,2}$, Xiaojing Liu ${ }^{1 *}$ \\ ${ }^{1}$ Key Laboratory of Agricultural Water Resources, Hebei Key Laboratory of Soil Ecology, \\ Center for Agricultural Resources Research, Institute of Genetics and Developmental Biology, \\ Chinese Academy of Sciences, Shijiazhuang, China \\ ${ }^{2}$ University of Chinese Academy of Sciences, Beijing, China
}

Received: 24 September 2019

Accepted: 9 December 2019

\begin{abstract}
Cultivation and growing salt-tolerant (halophytes) plants in coastal saline-alkali soils has been regarded as an effective way to reduce soil salinization and restore degraded vegetation. Planting halophytic plants generally alters soil properties and indirectly influences soil respiration. The aim of this paper is to evaluate the seasonal variation in soil respiration under different vegetation types in coastal saline-alkali land in northern China, and to identify how tree species, stand age, and soil properties (soil temperature, moisture, and salinity) explained the temporal and spatial variation in soil respiration. Soil respiration from halophytic plants (Tamarix chinensis and Lycium chinense) and salinealkali bare land were measured using an LI-COR 6400XT portable photosynthesis system equipped with a portable soil $\mathrm{CO}_{2}$ flux chamber from May to October 2016. The results indicated that $T$. chinensis and L. chinense shrub communities significantly reduced soil salinity, slightly reduced soil bulk density, improved soil organic carbon, and promoted the microbial community. Soil respiration from T. chinensis and L. chinense plantations were significantly higher than that from bare land. Coastal salinized bare land is a weak carbon source for global carbon. Soil respiration was generally restrained by soi salinity and reduced with increasing soil salinity. Soil respiration showed a positive and negative correlation ith soil temperature, moisture, and salinity. Incorporating salinity, together with soil temperature and other abiotic factors, may improve predictions for soil $\mathrm{CO}_{2}$ respiration.
\end{abstract}

Keywords: soil respiration, halophytic plant, soil salinity, Tamarix chinensis, Lycium chinense

\section{Introduction}

Soil salinity is a crucial constraint in the potential utilization of land resources in the coastal regions of northern China [1]. Most of the lands within these areas

*e-mail: xjliu@sjziam.ac.cn are covered with salinized soil and are accompanied by shallow underground water [2]. Excess salinity and alkalinity plagued seed germination and plant growth, and led to environmental degradation [3]. In order to improve these conditions, local governments have launched costal ecological restoration projects, including planting halophytes, to recover degraded vegetation and reduce soil salinization. Halophytic plants can grow well and produce high biomass in saline environments 
by utilizing saline lands and brackish water [4]. Some native halophytes such as Tamarix chinensis and Lycium chinense are shrub species known for their high tolerance to salinity, drought, and flooding stresses, and are usually used for soil improvement and vegetation restoration in coastal saline-alkali soil [5]. Along with local policies, we have been trying to improve coastal saline soils by irrigating with freezing saline water and then planting halophytes. In recent years we have selected several new $T$. chinensis varieties from local wild individuals. New $T$. chinensis varieties have straighter trunks, denser foliage, deeper green leaves, and longer growing seasons compared with ordinary ones [5]. Additionally, as salt-tolerant and edible species, L. chinense has attracted increasing attention for its ecological benefits and economic effects. $L$. chinense and new $T$. chinensis varieties have been planted widely in coastal regions because of their high economic effects as well as excellent landscape effects.

Accumulating evidence indicates that planting halophytes and anthropogenic cultivation could impact the distributions of water and salt in shallow soil [68]. Plant transpiration averts the accumulation of salts at the surface and gradually desalinizes the soil [8]. Jing et al. [9] reported that halophytes decreased shallow soil salinity and increased organic matter content and microbial biodiversity. Changes in soil salinity may play a pivotal role in regulating the variation in soil respiration from coastal saline-alkali soil [10-12]. Determining how halophytic plants and soil salinity influence soil respiration are necessary steps in assessing potential impacts of environmental change. Some studies found that, due to the contribution of sulfate reduction to the microbial respiration and carbon mineralization, soil respiration increased with seawater intrusion [13-14]. A decrease in soil respiration in wetland soils with increasing salinity has also often been shown by previous studies [15]. They attributed the variations in soil respiration to the alterations of microbial community composition [16]. Therefore, although many studies have focused on the response of soil respiration to moderate salt stress, the soil respiration from different halophytic plants within similar saline-alkali soils is poorly understood, and soil respiration from different heterogeneous saline-alkali soils remains unknown.

Understanding the effects of tree species in salinealkali soils on soil respiration can provide important information for ecosystem management practices and international policies to mitigate greenhouse gas emissions [17]. However, a comprehensive assessment of soil respiration from different halophytic plants has not been reported in China to date. The objectives of this study were to: (1) investigate the seasonal variation of soil respiration from saline-alkali soil plantings with different halophytic plants; and (2) identify how tree species, stand age, and soil salinity can help explain the temporal and spatial variation in soil respiration from coastal saline-alkali soil.

\section{Materials and Methods}

\section{Site Description}

The experiment was conducted in the coastal heavy saline-alkali land in Haixing County $\left(117^{\circ} 33^{\prime} 5^{\prime \prime} \mathrm{E}\right.$, N38 $8^{\prime} 59^{\prime \prime} \mathrm{N}$ ) of Hebei Province in northern China. Elevation ranges from 1.3 to $3.6 \mathrm{~m}$ a.s.l. This area has a typical semi-humid continental monsoon climate, with hot humid summers and cold dry winters. The annual average temperature is $12.1^{\circ} \mathrm{C}$. Annual precipitation averages $582 \mathrm{~mm}$, with nearly $74 \%$ falling in July through August and less than 7\% falling in the winter. Soils in the area are generally classified as silty clay loam, and soil salinity ranges from 4 to $30 \mathrm{~g} \mathrm{~kg}^{-1}$ [2]. The topography in the experiment site is generally flat with a very shallow groundwater table $(0.8-1.5 \mathrm{~m}$ depth), and groundwater salinity ranges from 25 to $35 \mathrm{~g} \mathrm{~L}^{-1}$ [2]. Both soil and groundwater salinity exhibited considerable spatial and temporal variations, and fluctuated with the variations in soil moisture [18].

Vegetation in the area is a mosaic of shrubs, herbs, plantation, and agricultural crops. The naturally regenerated herb community is dominated by Suaeda salsa, Ixeris polycephala, Aeluropus sinensis, and Phragmites australis. The planted species are $T$. chinensis, L. chinense, Fraxinus velutina, Hibiscus moscheutos, and Solanum nigrum. As most common vegetation types in saline-alkali soils, T. chinensis and $L$. chinense were selected as representative shrub species to study the effects of tree species, stand age, and soil salinity on soil respiration.

\section{Experiment Design}

T. chinensis of 3-year-old (3aT) and 10-year-old $(10 \mathrm{aT})$, and $L$. chinense of 2-year-old (2aL) and 8-yearold $(8 \mathrm{aL})$ are selected to represent managed shrubs in the region. Salinized bare land surrounding the main shrubs were selected as control (CK).

T. chinensis of 3-year-old was planted in 2013 with $1.3 \mathrm{~m}$ row spacing and $0.5 \mathrm{~m}$ plant spacing. Canopy height is about $2 \mathrm{~m}$. Canopy density is about $85 \%$. T. chinensis of 10-year-old was planted in 2006 with a planting density of $1 \mathrm{~m}$ (row spacing) and $0.6 \mathrm{~m}$ (plant spacing). Canopy height is about $3.2 \mathrm{~m}$. Canopy density is about $95 \%$. L. chinense of 2-year-old was planted in 2014 with $1.5 \mathrm{~m}$ row spacing and $0.6 \mathrm{~m}$ plant spacing. The overstory shrubs have an average height of $0.8 \mathrm{~m}$ and a canopy density of $75 \%$. L chinense of 8-year-old was planted in 2008 with a planting density of $2 \mathrm{~m}$ (row spacing) and $0.6 \mathrm{~m}$ (plant spacing). The overstory shrubs have an average height of $1 \mathrm{~m}$ and a canopy density of $85 \%$. To obtain a good germination rate, the $T$. chinensis and $L$. chinense seeds were planted and then covered with plastic film, which reduces evaporation and increases soil temperature and moisture. The plants were watered in the first year to 
Table 1. General characteristics of different vegetation types.

\begin{tabular}{|c|c|c|c|c|c|c|}
\hline & $\begin{array}{c}\text { Age } \\
(\text { Year })\end{array}$ & $\begin{array}{c}\text { Row spacing } \\
(\mathrm{m})\end{array}$ & $\begin{array}{c}\text { Plant spacing } \\
(\mathrm{m})\end{array}$ & $\begin{array}{c}\text { Height } \\
(\mathrm{m})\end{array}$ & $\begin{array}{c}\text { Coverage } \\
(\%)\end{array}$ & Understory \\
\hline \multirow{2}{*}{$\begin{array}{c}\text { Tamarisk } \\
\text { chinensis }\end{array}$} & 3 & 1.3 & 0.5 & 2 & 85 & $\begin{array}{c}\text { Suaeda salsa, Ixeris polycephala, } \\
\text { Aeluropus sinensis }\end{array}$ \\
\cline { 2 - 7 } & 10 & 1 & 0.6 & 3.2 & 95 & Ixeris polycephala, Aeluropus sinensis \\
\hline $\begin{array}{c}\text { Lycium } \\
\text { chinense }\end{array}$ & 2 & 1.5 & 0.6 & 0.8 & 75 & Suaeda salsa, Aeluropus sinensis \\
\cline { 2 - 7 } Bare land & 8 & 2 & 0.6 & 1 & 85 & Ixeris polycephala, Aeluropus sinensis \\
\hline
\end{tabular}

ensure emergence and survival, and no management measures were applied after that. One sampling plot $(20 \mathrm{~m} \times 20 \mathrm{~m})$ was randomly chosen for each shrub species to be the representative of that vegetation. The vegetation status and soil properties of each of the plots are listed in Tables 1 and 2, respectively.

\section{Measurement of Fluxes}

Soil respiration rates for the growing season (MayOctober 2016) in T. chinensis (3-year-old and 10-yearold), L. chinense (2-year-old and 8-year-old), and bare land were measured between 9:00 and 11:00 in the middle of each month using an LI-COR 6400XT portable photosynthesis system equipped with a portable soil $\mathrm{CO}_{2}$ flux chamber (LiCor-6400-09) (Lincoln, NE, USA). Soil temperature (at a depth of $10 \mathrm{~cm}$ ) was monitored simultaneously with the temperature sensor. In order to measure soil respiration, three PVC collars $(10 \mathrm{~cm}$ in diameter and $7 \mathrm{~cm}$ in height) were inserted $5 \mathrm{~cm}$ into the soil surface at each sampling point approximately 1 month before the first measurement. Small litter, such as leaves, fruits, and twigs, were left in the collar and coarse wood debris was removed. All collars were left at the site for the length of the entire experimental stage. Before every monthly measurement, living plants inside the collars were carefully removed by hand. The total length of each $\mathrm{CO}_{2}$ efflux measurement was about $3 \mathrm{~min}$. In addition, diurnal variation in soil respiration under different land uses (T. chinensis of 3-year-old and 10 -year-old, L. chinense of 2-year-old and 8-year-old, and bare land) from 8:00 and 18:00 were measured at $2 \mathrm{~h}$ intervals on 5 near-consecutive and clear days every month from May to October 2016. The zero and span gases for $\mathrm{CO}_{2}$ of the automated soil respiration systems were calibrated on an annual basis, anomalous data caused by mechanical faults, including a poor chamber seal, flow problems, or damaged instrumentation, was filtered.

To further study the effects of soil salinity on soil respiration, we conducted a complementary indoor observation experiment in which air-dried non-salinealkali soils collected from the open fields were passed through a soil sieve of $2 \mathrm{~mm}$ mesh and carefully packed in the chamber at a similar bulk density to the open fields. 1-year-old $T$. chinensis and $L$. chinense were planted under 6 salinity treatments $(\mathrm{NaCl})(0,3,6$, 9, 12, $15 \mathrm{~g} \mathrm{~kg}^{-1}$ for $T$. chinensis, and $0,5,10,15,20$, $25 \mathrm{~g} \mathrm{~kg}^{-1}$ for L. chinense, respectively). Twelve annual plants of $T$. chinensis or $L$. chinense were planted in each salinity treatment. Plants were watered regularly to maintain soil moisture similar to the open fields. Three well grown plants were selected from each salinity treatment, and one PVC collar was inserted $5 \mathrm{~cm}$ into the soil surface at each chamber approximately 1 month before the first measurement. Soil respiration rates and soil temperature in $T$. chinensis and L. chinense under different salinity treatments were measured between

Table 2. Physical and chemical properties of soil in different vegetation types.

\begin{tabular}{|c|c|c|c|c|}
\hline & & $\begin{array}{c}\text { Soil salinity } \\
\mathrm{g} \mathrm{kg}^{-1}\end{array}$ & $\begin{array}{c}\text { Soil organic carbon } \\
\mathrm{g} \mathrm{kg}^{-1}\end{array}$ & $\begin{array}{c}\text { Soil bulk density } \\
\mathrm{g} \mathrm{cm}^{-3}\end{array}$ \\
\hline \multirow{2}{*}{ Tamarisk chinensis } & $3 \mathrm{aT}$ & $6.47 \pm 0.47$ & $11.62 \pm 0.23$ & $1.48 \pm 0.02$ \\
\cline { 2 - 5 } & $10 \mathrm{aT}$ & $5.02 \pm 0.28$ & $12.29 \pm 0.27$ & $1.41 \pm 0.02$ \\
\hline \multirow{2}{*}{ Lycium chinense } & $2 \mathrm{aL}$ & $7.79 \pm 0.63$ & $9.85 \pm 0.40$ & $1.53 \pm 0.04$ \\
\cline { 2 - 5 } & $8 \mathrm{aL}$ & $6.68 \pm 0.42$ & $12.17 \pm 0.62$ & $1.46 \pm 0.03$ \\
\hline Bare land & & $27.92 \pm 1.81$ & $5.97 \pm 0.85$ & $1.57 \pm 0.22$ \\
\hline Potting soil & & $0.95 \pm 0.12$ & $6.85 \pm 0.96$ & \\
\hline
\end{tabular}

Note: 3aT: T. chinensis of 3-year-old, 10aT: T. chinensis of 10-year-old, 2aL: L. chinense of 2-year-old, 8aL:

L. chinense of 8-year-old. 
9:00 and 11:00 in the morning in the middle of each month from May-October in 2016.

Alongside soil respiration measurements, gravimetric soil moisture content was determined by collecting soil samples $(0.1 \mathrm{~kg})$ within $50 \mathrm{~cm}$ distance of the chambers at 0 to $10 \mathrm{~cm}$ depth. Fresh soil samples were weighed and transported to the laboratory, where they were oven-dried at $105^{\circ} \mathrm{C}$ for $24 \mathrm{~h}$ and weighed again, following which soil moisture content was determined.

\section{Soil Sampling and Analysis}

Soils were sampled at $0-10 \mathrm{~cm}$ in each sampling plots for measurement of soil salinity, soil organic
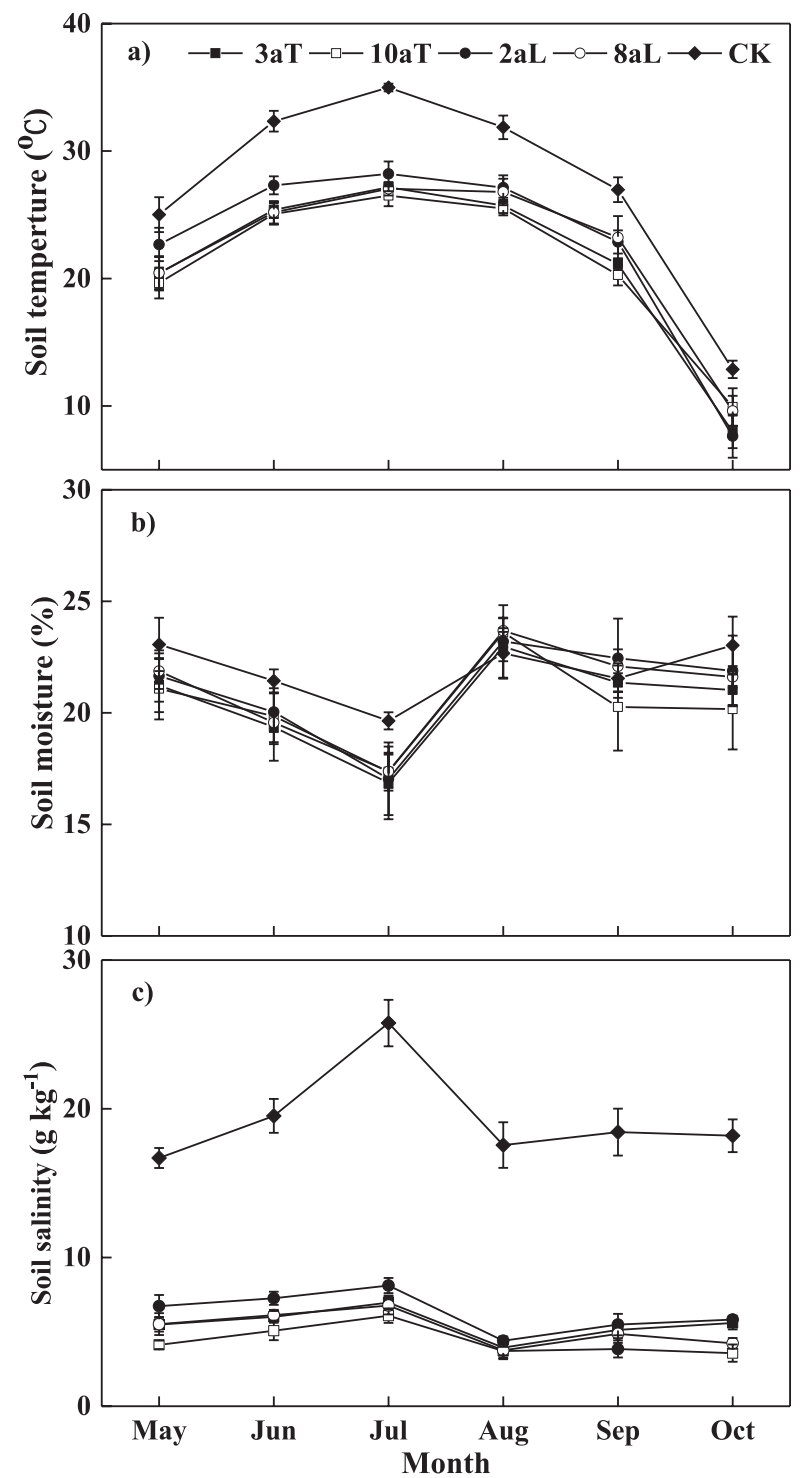

Fig. 1. Seasonal patterns of soil temperature at 0 to $10 \mathrm{~cm}$ depth a), soil gravimetric moisture b), and soil salinity c). 3aT: Three-year-old Tamarix chinensis; 10aT: Ten-year-old Tamarix chinensis; 2aL: Two-year-old Lycium chinense; 8aL: Eight-yearold Lycium chinense; CK: Saline bare land. Values represent the means \pm standard deviations $(n=3)$. carbon, soil bulk density, and the abundance of bacteria, fungi, and actinomycetes. For measurement of soil bulk density, the soil samples were weighed immediately and transported to the laboratory, where they were ovendried at $105^{\circ} \mathrm{C}$ for $24 \mathrm{~h}$ and reweighed for calculation of soil bulk density and soil water content.

To measure soil organic carbon content and soil salinity, the soil samples were air-dried and ground to pass a 100 -mesh screen prior to analysis. Soil organic carbon was measured by the $\mathrm{K}_{2} \mathrm{Cr}_{2} \mathrm{O}_{7}+\mathrm{H}_{2} \mathrm{SO}_{4}$ digestion method. The cation and anion contents of saline soils were analyzed in 1:5 soil water extracts [19]. $\mathrm{CO}_{3}{ }^{2-}$ and $\mathrm{HCO}_{3}^{-}$were determined by double indicator neutralization titration method, $\mathrm{SO}_{4}^{2-}$ was determined by EDTA volumetric method, $\mathrm{Cl}^{-}$was determined by $\mathrm{AgNO}_{3}$ titration method, $\mathrm{Ca}^{2+}$ and $\mathrm{Mg}^{2+}$ were determined by EDTA complexometric titration method, $\mathrm{Na}^{+}$and $\mathrm{K}^{+}$were analyzed by flame photometry method (wyx-402c, Shenyang, China), the total soil salinity is the sum content of $\mathrm{CO}_{3}{ }^{2-}, \mathrm{HCO}_{3}^{-}, \mathrm{SO}_{4}^{2-}, \mathrm{Cl}^{-}, \mathrm{Ca}^{2+}, \mathrm{Mg}^{2+}$, $\mathrm{Na}^{+}$, and $\mathrm{K}^{+}$.

For measuring microbial community abundance, fresh soil samples were transported to the laboratory, where the abundance of bacteria, fungi, and actinomycetes were analyzed using the real-time polymerase chain reaction (PCR) method [18].

\section{Statistical Analysis}

Statistical analyses were performed using the SPSS software package for Windows (Version 18.0, SPSS Inc., Chicago, Il, USA). The differences of soil microbial community abundance among shrub types and the impacts of soil salinity, soil temperature, and soil moisture on soil respiration were evaluated using oneway ANOVA followed by a Tukey multiple-comparison test at $\mathrm{P}<0.05$. Linear and exponential regression were used to evaluate the relationships between soil environmental variables and soil respiration.

\section{Results}

\section{Environmental Variables}

Soil temperature of growing seasons showed clear seasonal variation. The monthly mean soil temperature was $28.8 \pm 0.6^{\circ} \mathrm{C}$ (mean \pm S.E.) in July and $9.6 \pm 1.3^{\circ} \mathrm{C}$ in October (Fig. 1). The planting of $T$. chinensis and $L$. chinense reduced average soil surface temperature (Fig. 1). Gravimetric soil moisture was largely synchronized with precipitation, and mean soil moisture is $17.7 \%$ in July and $23.2 \%$ in August (Fig. 1). Soil salinity fluctuated with the variations in soil temperature and moisture, and mean soil salinity is $10.7 \mathrm{~g} \mathrm{~kg}^{-1}$ in July and $6.7 \mathrm{~g} \mathrm{~kg}^{-1}$ in August (Fig. 1, Table 2). The planting of $T$. chinensis and $L$. chinense reduced average soil salinity by $14.0 \mathrm{~g} \mathrm{~kg}^{-1}$ (Fig. 2). In terms of soil organic carbon, L. chinense of 8-year- 


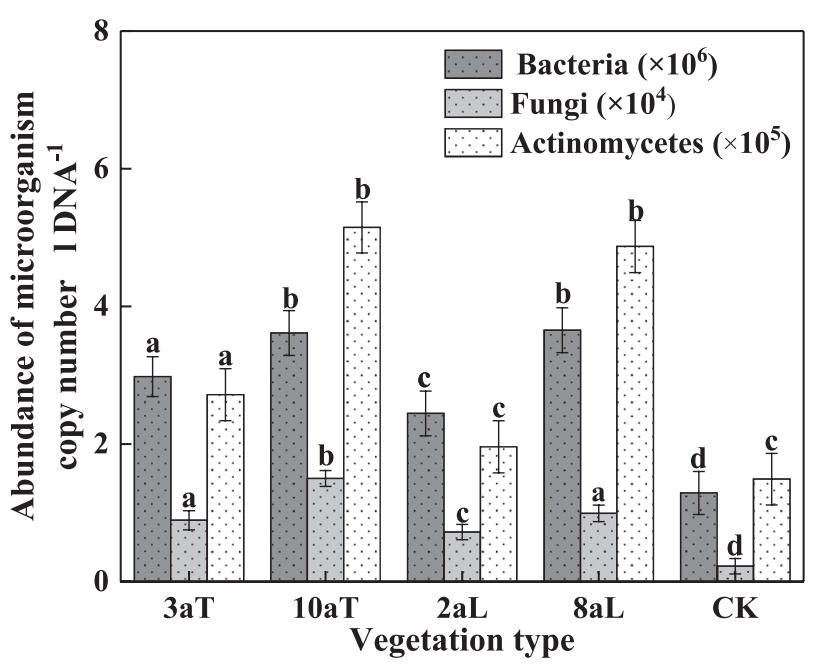

Fig. 2. Abundance of bacteria, fungi, and actinomycetes. The error bars represent the standard deviation of the means $(n=3)$. Different letters (a, b, and c) indicate significant differences between each land at $p<0.05$.

old (12.2 $\left.\mathrm{g} \mathrm{kg}^{-1}\right)$ and $T$. chinensis of 10-year-old (12.3 $\left.\mathrm{g} \mathrm{kg}^{-1}\right)$ had higher value, followed by $T$. chinensis of 3-year-old (11.6 $\left.\mathrm{g} \mathrm{kg}^{-1}\right)$ and L. chinense of 2-yearold $\left(9.8 \mathrm{~g} \mathrm{~kg}^{-1}\right)$, and salinized bare land $\left(6.0 \mathrm{~g} \mathrm{~kg}^{-1}\right) \mathrm{had}$ the lowest value (Table 2). The mean soil bulk density is $1.49 \mathrm{~g} \mathrm{~cm}^{-3}$, and the planting of $T$. chinensis and L. chinense slightly reduced soil bulk density (Table 2). There were significant differences in microbial community abundance $(P<0.05)$ among different shrub species, with higher values of bacteria, fungi and actinomycetes at the L. chinense of 8-year-old and T. chinensis of 10-year-old, followed by T. chinensis of 3-year-old and L. chinense of 2-year-old, the lowest value was recorded at salinized bare land (Fig. 2). The abundance of the microbial community increased with increasing stand age (Fig. 2).

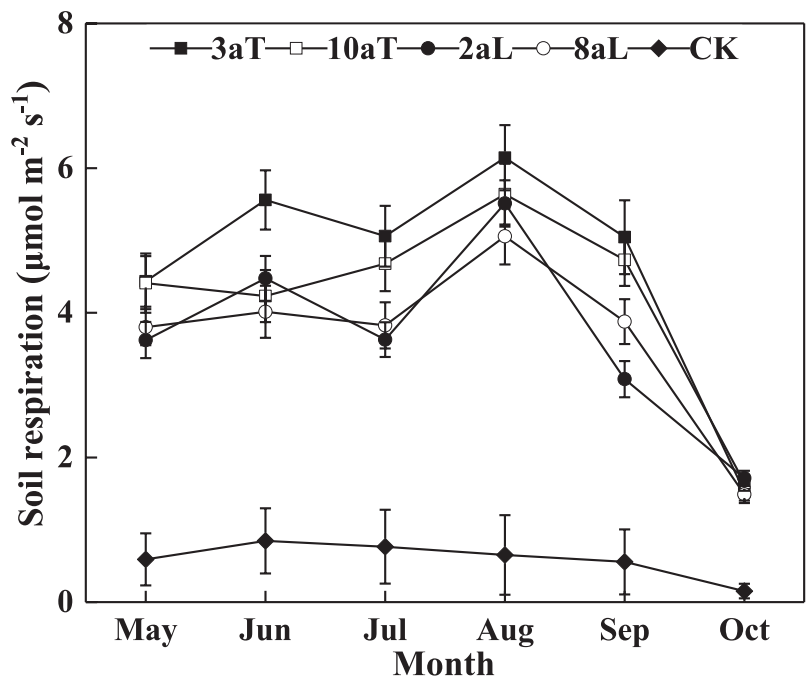

Fig. 3. Seasonal patterns of soil respiration under different land use types.

\section{Soil Respiration}

Soil respiration of growing seasons in $T$. chinensis, L. chinense, and salinized bare land were on average $4.43,3.68$, and $0.59 \mu \mathrm{mol} \mathrm{m} \mathrm{m}^{-2} \mathrm{~s}^{-1}$, respectively (Fig. 3). Soil respiration from shrub communities were significantly higher than that from bare land. In terms of different vegetation, soil respiration from $T$. chinensis was slightly higher than that from L. chinense (Fig. 3). There were no significant differences in soil respiration for different stand ages (Fig. 3). Seasonal changes in soil respiration followed a pattern similar to that of soil temperature. Soil respiration was moderate in late spring (mean $3.37 \mu \mathrm{mol} \mathrm{m} \mathrm{m}^{-2} \mathrm{~s}^{-1}$ in May), increased sharply to a peak in summer (mean $4.60 \mu \mathrm{mol} \mathrm{m} \mathrm{m}^{-2} \mathrm{~s}^{-1}$ in August), and then decreased in autumn (mean $1.31 \mu \mathrm{mol} \mathrm{m} \mathrm{m}^{-2} \mathrm{~s}^{-1}$ in October) (Fig. 3). The diurnal soil respiration across the different vegetation types was similar in different months, and could be expressed as a single peak curve (Fig. 4). In general, soil respiration reached its daily maximum $\left(0.76-5.30 \mu \mathrm{mol} \mathrm{m} \mathrm{m}^{-2} \mathrm{~s}^{-1}\right)$ between 12:00 and 14:00, coinciding with peak photosynthetic rate (Fig. 4). Across different vegetation types, the diurnal soil respiration from $T$. chinensis and L. chinense were significantly higher than that from bare land (Fig. 4). There were no significant differences in diurnal soil respiration for different vegetation types and stand ages (Fig. 4).

We found significant differences in soil respiration from $T$. chinensis (range 0.16-4.13 $\mu \mathrm{mol} \mathrm{m} \mathrm{m}^{-2} \mathrm{~s}^{-1}$ ) and

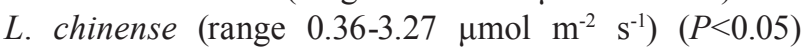
under different soil salinities (Fig. 5). Soil respiration was generally restrained by soil salinity and reduced with increasing soil salt content, soil respiration was suppressed by additional soil salinity when soil salt content in $T$. chinensis and L. chinense exceeded $15 \mathrm{~g} \mathrm{~kg}^{-1}$ and $9 \mathrm{~g} \mathrm{~kg}^{-1}$, respectively (Fig. 5). Similar to the seasonal pattern of soil respiration in the open fields,

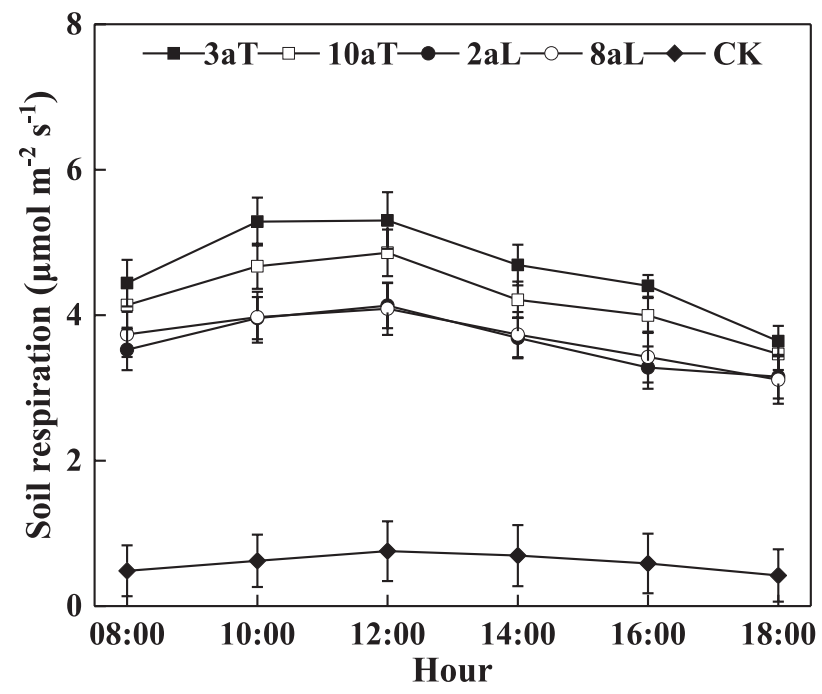

Fig. 4. Diurnal variation of soil respiration under different land use types. 

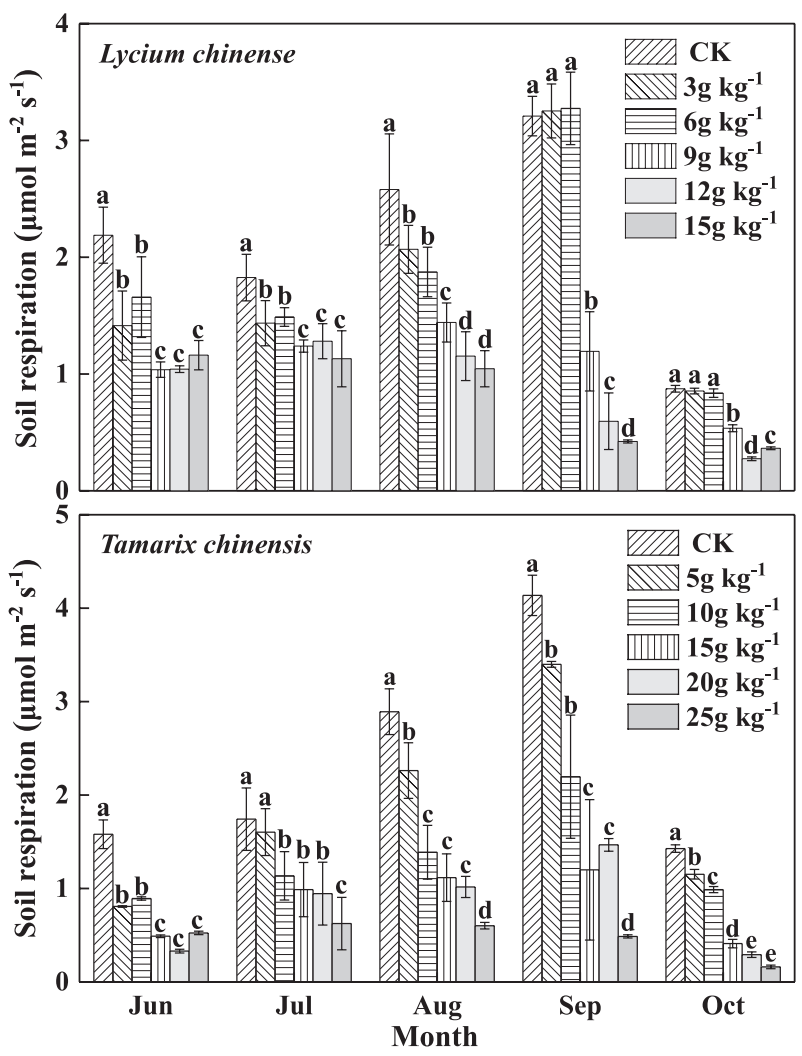

Fig. 5. Soil respiration under different soil salinities.

monthly mean soil respiration indoors under different soil salinities increased from $1.09 \mu \mathrm{mol} \mathrm{m} \mathrm{m}^{-2} \mathrm{~s}^{-1}$ in May up to $1.62 \mu \mathrm{mol} \mathrm{m} \mathrm{m}^{-2} \mathrm{~s}^{-1}$ in June, and then decreased gradually to $0.68 \mu \mathrm{mol} \mathrm{m} \mathrm{m}^{-2} \mathrm{~s}^{-1}$ in October (Fig. 5).

\section{Relationship of Soil Respiration with Soil Temperature, Moisture, and Salinity}

Soil respiration showed a significant positive correlation with soil temperature $(P<0.01)$, and the exponential equation model showed a better explanatory power $\left(\mathrm{R}^{2}\right)$ in describing the dependency

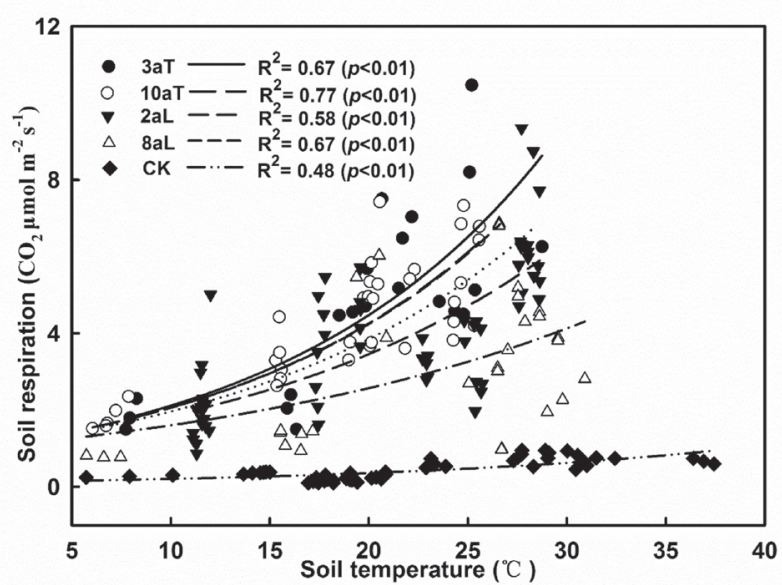

Fig. 6. Relationship between soil respiration and soil temperature.
Table 3. Relationship of soil respiration with soil temperature, moisture, and salinity

\begin{tabular}{|c|c|c|c|c|}
\hline & & $\begin{array}{c}\text { Soil } \\
\text { temperature }\end{array}$ & $\begin{array}{c}\text { Soil } \\
\text { moisture }\end{array}$ & $\begin{array}{c}\text { Soil } \\
\text { salinity }\end{array}$ \\
\hline \multirow{4}{*}{$\begin{array}{c}\text { Soil } \\
\text { respiration }\end{array}$} & $3 \mathrm{aT}$ & $0.67^{* *}$ & 0.37 & $-0.48^{*}$ \\
\cline { 2 - 5 } & $10 \mathrm{aT}$ & $0.77^{* *}$ & 0.18 & 0.25 \\
\cline { 2 - 5 } & $2 \mathrm{aL}$ & $0.58^{* *}$ & 0.43 & $-0.53^{*}$ \\
\cline { 2 - 5 } & $8 \mathrm{aL}$ & $0.67^{* *}$ & 0.32 & -0.11 \\
\cline { 2 - 5 } & $\mathrm{CK}$ & $0.48^{* *}$ & -0.12 & 0.11 \\
\hline
\end{tabular}

Note: $*: p<0.05 ; * *: p<0.01$

of soil respiration on soil temperature (Fig. 6). Soil respiration showed no significant correlation with soil moisture (Table 3). Increasing salinization reduced soil respiration from T. chinensis and L. chinense (Fig. 7). The linear model showed a better explanatory power $\left(\mathrm{R}^{2}\right)$ in describing the dependency of soil respiration on soil salinity (Fig. 7).

\section{Discussion}

Cultivating and growing halophytic plants significantly reduced soil salinity. Due to its strong salinity, saline-alkali and drought stress tolerance, $T$. chinensis and $L$. chinense can adapt to adverse environments such as abandoned saline-alkali soils, which is not suitable for growing plants due to the high soil salinity and barren soil nutrients. After several years of growth, the mean soil salinity, initially similar in all vegetation types, had decreased by 22.2 and $20.7 \mathrm{~g} \mathrm{~kg}^{-1}$ in soil cultivated with $T$. chinensis and L. chinense, respectively. Our findings are comparable to numerous field studies that have confirmed the capacity of $T$. chinensis and L. chinense to reduce soil salinity [20-21]. Salt leaching via water

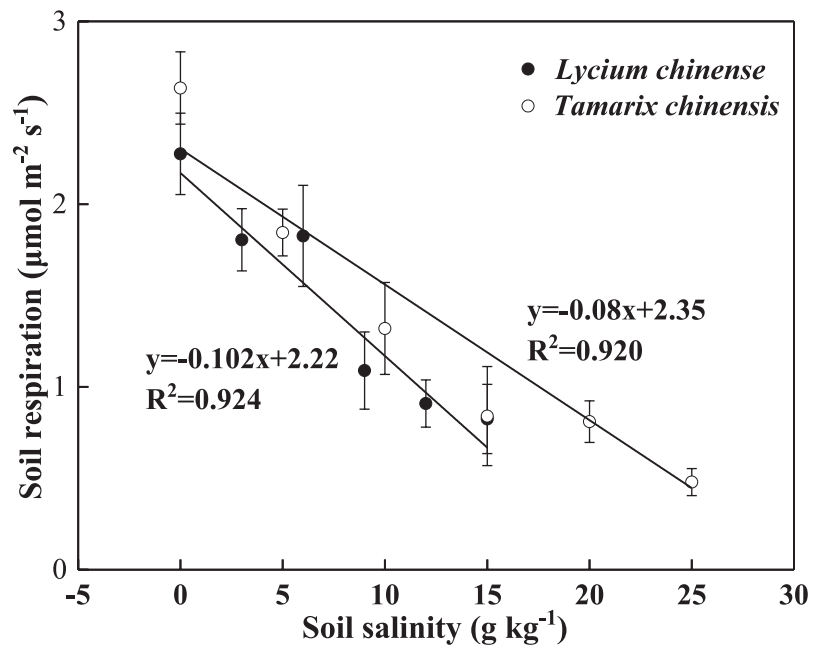

Fig. 7. Relationship between soil respiration and soil salinity. 
infiltration or accumulation in plant biomass were the main processes of soil desalinization [6, 22-23]. Plant roots can increase the number of bioport channels, which become preferential flow pathways for water infiltration and salt leaching [24]. In addition, halophytes such as T. chinensis and S. salsa could absorb large amounts of salt from the soil, and weakened soil salinity [6]. Ado et al. [21] reported that salt accumulation in plant biomass contributes significantly to soil desalinization, while salt accumulation in plant biomass contributed $22-35 \%$ of soil desalinization. This suggests that salt accumulation in plant biomass decreased soil salinity considerably.

Cultivating and growing halophytes improved soil organic carbon. After several years of growth corresponding to bare land, the mean soil organic carbon increased by 5.99 and $5.04 \mathrm{~g} \mathrm{~kg}^{-1}$ in soil cultivated with T. chinensis and L. chinense, respectively - similar to the observations of Qi et al. [20], who reported that planting Elaeagnus angustifolia in salt-affected coastal soils increased soil organic matter, total nitrogen and alkaline hydrolysis nitrogen. Zhao et al. [25] also reported that revegetation with $S$. salsa in coastal wetlands improved the input and accumulation of soil organic matter. Soil organic carbon is the major source of plant nutrients, and its quantity and quality are directly influenced by the plant community. T. chinensis and L. chinense had many branches that could cover the surface and reduce transpiration, and $T$. chinensis has numerous leaves and roots, the decomposition of litter and roots could improve soil physical and chemical properties, and in turn had a positive effect on plants [26]. This improvement in soil fertility is further evidence that afforestation with halophytes can be a sustainable land use option for the degraded coastal saline-alkali soils in China. In addition to soil carbon accumulation, afforestation in degraded saline-alkali soils can become important for carbon sequestration in biomass and hence the emerging carbon market [27].

Cultivation and growing halophytes promoted the microbial community. After several years of growth, the abundance of bacteria, fungi and actinomycetes were found to be higher in the soils associated with T. chinensis and L. chinense than in bare land. Similar results have been reported in numerous studies on other halophytes [9, 28-29]. Chaudhary et al. [29] found that halophytes increased the microbial and enzyme activities, and played a pivotal role in shaping microbial community structure. Jing et al. [9] reported that bacterial species richness and diversity were increased after the cultivation of halophytes (Atriplex triangularis and $S$. glauca), which generally influenced belowground processes of saline-alkali soils by nutrient cycling and litter decomposition. The differences in soil microbial community among halophyte species and in abandoned saline-alkali soils could be closely related with root exudates and plant litters [29]. In addition, halophytic plants can reduce rhizosphere soil salinity, and then reduce the effect of salinity stress on soil microbes [6].
Coastal wetlands are considered a significant sink for global carbon [30], and Xie et al. [31] reported that alkaline/saline soils can absorb $\mathrm{CO}_{2}$ at a rate of 0.3-3.0 $\mu \mathrm{mol} \mathrm{m} \mathrm{m}^{-2} \mathrm{~s}^{-1}$ with an inorganic, non-biological process. However, unlike these earlier studies, our research has shown that the mean soil respiration of growing seasons in salinized bare land was $0.59 \mu \mathrm{mol} \mathrm{m} \mathrm{m}^{-2} \mathrm{~s}^{-1}$, which is similar to the observations of Lai et al. [32], who found negative soil respiration only when the temperature was below $5^{\circ} \mathrm{C}$ in natural ecosystems of saline/alkaline soils. Regarding negative soil respiration, Xie et al. [31] confirmed that alkaline and saline soils absorb $\mathrm{CO}_{2}$ under natural conditions. If so, in view of the low soil organic carbon content in alkaline and saline soils, where does this absorbed $\mathrm{CO}_{2}$ eventually go? In addition, Parsons et al. [33] considered that a negative $\mathrm{CO}_{2}$ flux was associated with decreasing soil temperatures. Therefore, we expanded the observation of soil respiration to include the non-growing seasons, which may help explain this phenomenon.

Soil moisture was one of the most important regulating variables on soil respiration, but our study did not observe any response of soil respiration to soil moisture. Similar phenomena have been reported in previous studies [32, 34]. As a single factor, soil moisture failed to explain the variations in soil respiration in the growing season [32]. The response patterns of soil respiration to soil moisture were complex, with previous studies detecting a positive, negative, or no correlation between soil moisture and soil respiration in different ecosystems [35-36]. Gaumont-Guay et al. [37] reported that soil respiration increased with increasing soil moisture, but excessive soil moisture depresses soil respiration by limiting the transport of $\mathrm{CO}_{2}$ in the soil profile. Suseela et al. [38] reported that soil respiration in a mesic ecosystem decreased sharply when soil moisture dropped below $15 \%$ or exceeded $26 \%$, and increased gradually when soil moisture rose from the lower threshold. Wood et al. [39] found a significant parabolic relationship between soil respiration and soil moisture in humid tropical forests with peak soil respiration occurring at $37.5 \%$ of soil moisture. At our study site, soil moisture had a narrow range from $16.9 \%$ to $23.7 \%$, and showed almost no correlation with soil respiration. We speculate that this was due to the very shallow groundwater table, for which there was no water stress.

Salinity is one of the most important factors affecting soil respiration in saline-alkali soils, and our study showed that soil respiration decreased with increasing salinity. The negative impact of salinity on soil respiration was in agreement with previous studies [34, 40-41]. Salinity/alkalinity played a more important role in regulating soil respiration through its effects on the microorganisms, including microbial biomass, population, community structure and activity [32, 34]. When microbial community structure is affected, the numbers of bacteria, fungi, and actinomycetes 
dwindle, and then negatively affect soil respiration [34]. On the other hand, contradictory results have been obtained for the effects of salinity/alkalinity on soil respiration. Marton et al. [42] and Chambers et al. [13] found that soil respiration increased with seawater intrusion, which perhaps may be due to the contribution of sulfate reduction to the microbial respiration and carbon mineralization [43]. Moreover, Wong et al. [44] found that carbon mineralization increased with increasing salinity. This suggests that there may be a salinity threshold regulating soil respiration from alkaline-saline soils. As soil respiration is a complex process, many environmental factors including temperature, moisture, and salinity could regulated soil respiration. Thus, incorporating salinity together with soil temperature and other abiotic factors may improve predictions for soil $\mathrm{CO}_{2}$ respiration.

\section{Conclusions}

Cultivation and growing halophytes generally altered soil properties. Planting $T$. chinensis and $L$. chinense significantly reduced soil salinity, slightly reduced soil bulk density, improved soil organic carbon, and promoted the microbial community. Soil respiration from shrub communities was significantly higher than that from bare land. Coastal salinized bare land is a weak carbon source for global carbon. Soil respiration was generally restrained by soil salinity and reduced with increasing soil salinity. Soil respiration showed a positive and negative correlation with soil temperature, moisture, and salinity, respectively. Incorporating salinity together with soil temperature and other abiotic factors may improve predictions for soil $\mathrm{CO}_{2}$ respiration.

\section{Acknowledgements}

This research was supported by the National Key Technologies R\&D Program of China (2013BAD05B02, 2013BAD05B05) and the Science and Technology Service Network Program of the Chinese Academy of Sciences (KFJ-SW-STS-141-04-1).

\section{Conflict of Interest}

The authors declare no conflict of interest.

\section{References}

1. ZHANG T., WANG T., LIU K.S., WANG L., WANG K., ZHOU Y. Effects of different amendments for the reclamation of coastal saline soil on soil nutrient dynamics and electrical conductivity responses. Agr. Water Manage. 159, 115, 2015

2. FENG X., AN P., LI X., GUO K., YANG C., LIU X. Spatiotemporal heterogeneity of soil water and salinity after establishment of dense-foliage Tamarix chinensis on coastal saline land. Ecol. Eng. 121, 104, 2018.

3. GUO K., LIU X. Dynamics of meltwater quality and quantity during saline ice melting and its effects on the infiltration and desalinization of coastal saline soils. Agr. Water Manage. 139, 1, 2014.

4. KHAN M.A., ANSARI R., ALI H., GUL B., NIELSEN B.L. Panicum turgidum, a potentially sustainable cattle feed alternative to maize for saline areas. Agr. Ecosyst. Environ. 129 (4), 542, 2009.

5. FENG X., AN P., GUO K., LI X., LIU X., ZHANG X. Growth, root compensation and ion distribution in Lycium chinense under heterogeneous salinity stress. Sci. Hortic. 226, 24, 2017.

6. CAO D., SHI F., KOIKE T., LU Z., SUN J. Halophyte plant communities affecting enzyme activity and microbes in saline soils of the Yellow River Delta in China. CLEAN - Soil Air Water 42 (10), 1433, 2014.

7. CUI X., HU J., WANG J., YANG J., LIN X. Reclamation negatively influences arbuscular mycorrhizal fungal community structure and diversity in coastal salinealkaline land in Eastern China as revealed by Illumina sequencing. Appl. Soil Ecol. 98, 140, 2016.

8. LI X., XIA J., ZHAO X., CHEN Y. Effects of planting Tamarix chinensis on shallow soil water and salt content under different groundwater depths in the Yellow River Delta. Geoderma 335, 104, 2019.

9. JING C.L., XU Z.C., ZOU P., TANG Q., LI Y.Q., YOU X.W., ZHANG C.S. Coastal halophytes alter properties and microbial community structure of the saline soils in the Yellow River Delta, China. Appl. Soil Ecol. 134, 1, 2019.

10. WESTON N.B., VILE M.A., NEUBAUER S.C., VELINSKY D.J. Accelerated microbial organic matter mineralization following salt-water intrusion into tidal freshwater marsh soils. Biogeochemistry 102 (1-3), 135, 2011.

11. DRAKE P.L., MCCORMICK C.A., SMITH M.J. Controls of soil respiration in a salinity-affected ephemeral wetland. Geoderma 221, 96, 2014.

12. OLSSON L., YE S., YU X., WEI M., KRAUSS K.W., BRIX H. Factors influencing $\mathrm{CO}_{2}$ and $\mathrm{CH}_{4}$ emissions from coastal wetlands in the Liaohe Delta, Northeast China. Biogeosciences 12 (16), 4965, 2015.

13. CHAMBERS L.G., DAVIS S.E., TROXLER T., BOYER J.N., DOWNEY-WALL A., SCINTO L.J. Biogeochemical effects of simulated sea level rise on carbon loss in an Everglades mangrove peat soil. Hydrobiologia 726 (1), 195, 2014.

14. NEUBAUER S.C., FRANKLIN R.B., BERRIER D.J. Saltwater intrusion into tidal freshwater marshes alters the biogeochemical processing of organic carbon. Biogeosciences 10 (12), 8171, 2013.

15. YANG J., ZHAN C., LI Y., ZHOU D., YU Y., YU J. Effect of salinity on soil respiration in relation to dissolved organic carbon and microbial characteristics of a wetland in the Liaohe River estuary, Northeast China. Sci. Total Environ. 642, 946, 2018.

16. TRIPATHI S., KUMARI S., CHAKRABORTY A., GUPTA A., CHAKRABARTI K., BANDYAPADHYAY B.K. Microbial biomass and its activities in salt-affected coastal soils. Biol. Fert. Soils 42 (3), 273, 2006.

17. XIA J., ZHANG S., GUO J., RONG Q., ZHANG G. Critical effects of gas exchange parameters in Tamarix chinensis Lour on soil water and its relevant environmental factors on a shell ridge island in China's Yellow River Delta. Ecol. Eng. 76, 36, 2015. 
18. LI X., GUO K., FENG X., LIU H., LIU X. Soil respiration response to long-term freezing saline water irrigation with plastic mulching in coastal saline plain. Sustainability 9 (4), 621, 2017.

19. BAO S. Soil agricultural chemistry analysis. Higher Education Press, Beijing, 188, 1999.

20. QI Y., LI J., CHEN C., LI L., ZHENG X., LIU J., ZHU T., PANG C., WANG B., CHEN M. Adaptive growth response of exotic Elaeagnus angustifolia L. to indigenous saline soil and its beneficial effects on the soil system in the Yellow River Delta, China. Trees 32 (6), 1723, 2018.

21. ADO M.N., MICHOT D., GUERO Y., HALLAIRE V., DAN LAMSO N., DUTIN G., WALTER C. Echinochloa stagnina improves soil structure and phytodesalinization of irrigated saline sodic Vertisols. Plant Soil 434 (1), 413, 2019.

22. BARBIERO L., VALLES V., REGEARD A., CHEVERRY C. Residual alkalinity as tracer to estimate the changes induced by forage cultivation in a non-saline irrigated sodic soil. Agr. Water Manage. 50 (3), 229, 2001.

23. ADO M.N., GUERO Y., MICHOT D., SOUBEIGA B., KIESSE T.S., WALTER C. Phytodesalinization of irrigated saline Vertisols in the Niger Valley by Echinochloa stagnina. Agr. Water Manage. 177, 229, 2016.

24. LOGSDON S.D. Root effects on soil properties and processes: synthesis and future research needs: Advances in agricultural systems modeling. 2013.

25. ZHAO Q., BAI J., ZHANG G., JIA J., WANG W., WANG $X$. Effects of water and salinity regulation measures on soil carbon sequestration in coastal wetlands of the Yellow River Delta. Geoderma 319, 219, 2018.

26. RUIZ-SINOGA J.D., GABARRON GALEOTE M.A., MARTINEZ MURILLO J.F., GARCIA MARIN R. Vegetation strategies for soil water consumption along a pluviometric gradient in southern Spain. Catena 84 (1-2), 12, 2011.

27. KHAMZINA A., LAMERS J.P.A., VLEK P.L.G. Nitrogen fixation by Elaeagnus angustifolia in the reclamation of degraded croplands of Central Asia. Tree Physiol. 29 (6), 799, 2009.

28. SHI Y-W., LOU K., LI C., WANG L., ZHAO Z-Y., ZHAO S., TIAN C-Y. Illumina-based analysis of bacterial diversity related to halophytes Salicornia europaea and Sueada aralocaspica. J Microbiol. 53 (10), 678, 2015.

29. CHAUDHARY D.R., KIM J., KANG H. Influences of different halophyte vegetation on soil microbial community at temperate salt marsh. Microbial Ecology. 75 (3), 729, 2018

30. HAN G., SUN B., CHU X., XING Q., SONG W., XIA J. Precipitation events reduce soil respiration in a coastal wetland based on four-year continuous field measurements. Agr. Forest Meteorol. 256, 292, 2018.

31. XIE J., LI Y., ZHAI C., LI C., LAN Z. $\mathrm{CO}_{2}$ absorption by alkaline soils and its implication to the global carbon cycle. Environ. Geol. 56 (5), 953, 2009.
32. LAI L., ZHAO X., JIANG L., WANG Y., LUO L., ZHENG Y., CHEN X., RIMMINGTON G.M. Soil respiration in different agricultural and natural ecosystems in an arid region. Plos One 7 (10), 2012.

33. PARSONS A.N., BARRETT J.E., WALL D.H., VIRGINIA R.A. Soil carbon dioxide flux in antarctic dry valley ecosystems. Ecosystems 7 (3), 286, 2004.

34. LI Y., ZHAO M., LI F. Soil respiration in typical plant communities in the wetland surrounding the high-salinity Ebinur Lake. Front. Earth Sci. 12 (3), 611, 2018.

35. RETH S., REICHSTEIN M., FALGE E. The effect of soil water content, soil temperature, soil $\mathrm{pH}$-value and the root mass on soil $\mathrm{CO}_{2}$ efflux - A modified model. Plant Soil 268 (1-2), 21, 2005.

36. JIA B.R., ZHOU G.S., WANG F.Y., WANG Y.H., WENG E.S. Effects of grazing on soil respiration of Leymus chinensis steppe. Climatic Change 82 (1-2), 211, 2007.

37. GAUMONT-GUAY D., BLACK T.A., GRIFFIS T.J., BARR A.G., JASSAL R.S., NESIC Z. Interpreting the dependence of soil respiration on soil temperature and water content in a boreal aspen stand. Agr. Forest Meteorol. 140 (1-4), 220, 2006.

38. SUSEELA V., CONANT R.T., WALLENSTEIN M.D., DUKES J.S. Effects of soil moisture on the temperature sensitivity of heterotrophic respiration vary seasonally in an old-field climate change experiment. Global Change Biol. 18 (1), 336, 2012.

39. WOOD T.E., DETTO M., SILVER W.L. Sensitivity of soil respiration to variability in soil moisture and temperature in a humid tropical forest. Plos One 8 (12), 2013.

40. MAUCIERI C., ZHANG Y., MCDANIEL M.D., BORIN M., ADAMS M.A. Short-term effects of biochar and salinity on soil greenhouse gas emissions from a semiarid Australian soil after re-wetting. Geoderma 307, 267, 2017.

41. ZHANG L., SONG L., WANG B., SHAO H., ZHANG L., QIN X. Co-effects of salinity and moisture on $\mathrm{CO}_{2}$ and $\mathrm{N}_{2} \mathrm{O}$ emissions of laboratory-incubated salt-affected soils from different vegetation types. Geoderma 332, 109, 2018

42. MARTON J.M., HERBERT E.R., CRAFT C.B. Effects of salinity on denitrification and greenhouse gas production from laboratory-incubated tidal forest soils. Wetlands $\mathbf{3 2}$ (2), 347, 2012.

43. BROUNS K., VERHOEVEN J.T.A., HEFTING M.M. The effects of salinization on aerobic and anaerobic decomposition and mineralization in peat meadows: The roles of peat type and land use. J. Environ. Manage. 143, 44, 2014.

44. WONG V.N.L., DALAL R.C., GREENE R.S.B. Carbon dynamics of sodic and saline soils following gypsum and organic material additions: A laboratory incubation. Appl. Soil Ecol. 41 (1), 29, 2009. 
